\title{
State Failure, Polarisation, and Minority Engagement in Germany's Refugee Crisis
}

\author{
Jan-Jonathan Bock ${ }^{1}$
}

Published online: 31 May 2018

(C) The Author(s) 2018

\begin{abstract}
Talk about a 'refugee crisis' dominated Germany's political discourse in 2015/2016. The arrival of hundreds of thousands of foreigners desiring protection shaped public and private debates. However, rather than taking the term refugee crisis for granted, this article suggests that critical experiences in Germany, and responses to them, were shaped by the failure of state institutions. In the same year, as further austerity measures were imposed on Greece, German citizens questioned the state of their own public infrastructure. Following privatisation and cuts to social services, national, regional, and local authorities lacked the capacity to respond adequately to newcomers' needs. The sight of failing state institutions contributed to a sense of crisis. Simultaneously, however, the apparent state incapacityparticularly also in Berlin, the focus of this article - opened up spaces for emergent civil society actors, including minority groups. Muslims organised in associations could perform relevance as reliable citizens and raise their public profile. Different groups also put forward alternative visions of society. At the same time, government support for asylum seekers and the greater visibility of actors in a pluralist society pushed some conservatives towards a new farright force: the Alternative for Germany party (AfD). The gaps in public administration that were revealed in 2015/2016 resulted in social polarisation left and right of centrist politics: nationalist conservatives rejected an increasingly multicultural country and found a new political home in the AfD, whereas left wingers and minority groups challenged austerity and claimed greater political representation for their views.
\end{abstract}

Keywords Austerity $\cdot$ Civil society $\cdot$ Crisis $\cdot$ Germany $\cdot$ Populism $\cdot$ Refugees

Over the course of only a few months, the so-called refugee crisis (Flüchlingskrise) and its implications upended German political discourse in the summer of 2015. Previously, the dominant topic had been Greece's new socialist government, led by Alexis Tsipras, and the

Jan-Jonathan Bock

jjbock@cumberlandlodge.ac.uk

1 Cumberland Lodge, The Great Park, Windsor SL4 2HP, UK 
country's fight against austerity. Germany's politicians and the public argued over rescue packages and Greece's flamboyant Finance Minister, Yannis Varoufakis. Questions about debt and German supremacy tested solidarity among EU member states as old stereotypes returned. In anti-austerity protests, posters depicted Germany's Chancellor, Angela Merkel, wearing Nazi uniform. In 2010, the German weekly news magazine Focus had published a contentious cover that showed a statue of the goddess Aphrodite with an erect middle finger, seemingly directed at Greece's European lenders. The headline: 'Crooks in the euro family. Is Greece stealing our money - and what about Spain, Portugal, Italy?' The play on prejudices about Mediterranean profligacy led to a Greek court case about the defamation of national symbols. Two years later, the Italian newspaper Il Giornale raised eyebrows with its cover image of Angela Merkel, her right arm accidently raised, under the headline 'Fourth Reich'. Opposition was also forming at home: in 2012, the sociologist Ulrich Beck, author of Risk Society (Beck 1992), attacking German dominance and austerity in his book Deutsches Europa. ${ }^{1}$

On 17 July 2015, the German Parliament passed a motion in favour of negotiations for a third EU rescue intervention in Greece. The Left Party and the Greens attacked the conditions as too harsh. On the other side, the government majority - a so-called grand coalition of the conservative CDU, its Bavarian sister party, the CSU, and the social democratic SPD struggled to discipline centre-right MPs. ${ }^{2} 60$ conservative parliamentarians voted against negotiations, thereby defying Merkel's leadership. The public debate about the rescue package, worth 86 billion euros, was divisive: a survey in July 2015, at a time when Greece featured daily in the news, showed that $52 \%$ of Germans were in favour of government support, whereas $44 \%$ were against providing more credit; $45 \%$ of respondents wanted Greece to remain in the euro zone, while $45 \%$ suggested the opposite (http://www.infratest-dimap. de/umfragen-analysen/bundesweit/ard-deutschlandtrend/2015/juli-extra/). Media reports on Greece veered between tax evasion and social security fraud, and food banks, skyrocketing unemployment, and high suicide rates. At the same time-as Ulrich Beck described in Deutsches Europa (2012) — there was little official recognition for Germany's influence on deteriorating living conditions in Mediterranean countries. Beck accused Merkel of using hesitation and indifference to corroborate her power across a continent battered by economic decline. The sociologist attributed her political success to one particular ability: 'her tendency not to act at all, to decide the time is not yet ripe, to act at a later date - in short, to procrastinate. In the European crisis, Merkel delayed taking decisions from the very outset' (Beck 2013, p. 47 ). The characteristic lack of decisiveness even entered German youth language. In 2014/2015, the neologism merkeln appeared: the verb describes someone who uses opaque and unclear language. Merkeln means being evasive and boringly incomprehensible.

This article shows that reactions to the arrival of hundreds of thousands of asylum seekers in 2015/2016 should not be reduced to pressing questions of cultural otherness. Instead, I argue that the ways in which Germans engaged with sudden developments must be understood within a framework of long-term social and political trends. In this article, I put forward three central arguments: (1) the refugee crisis was really a crisis of public administration, forcing Germans to reflect on the quality and responsibility of state institutions; (2) the apparent

\footnotetext{
${ }^{1}$ Later published in English as German Europe (Beck 2013).

2 The Christian Social Union (CSU) is an independent party. However, it operates exclusively in the region of Bavaria, where the Christian Democratic Union (CDU), which otherwise operates nationwide, does not field candidates for local, regional, or national elections. The two are commonly referred to as sister parties (Schwesterparteien), or 'the Union' (die Union), and form a coherent block in parliament, even though tensions between Angela Merkel's centrism and the CSU's Bavarian nationalism mounted in recent years.
} 
incapacity of many institutions, particularly also in Berlin, to register and integrate asylum seekers opened up spaces for civil society actors, including minority groups, to perform social relevance and put forwards different visions of society after years of stagnant centrist politics; and (3) for the more conservative group of CDU/CSU voters, however, the government's response confirmed suspicion that the parties did no longer reflect the values of traditionalists, leading to the rise of a rightwing populist party, the Alternative for Germany (AfD).

Reactions to the 'refugee crisis' expose a particular socio-political context. Hence, the very term, Flüchtlingskrise - by portraying multiple and layered developments as a chaotic crisis induced by the arrival of refugees, and by their difference (Kosnick 2018)-reduced complex changes to the supposed problem of culture, and thereby eclipsed other, perhaps more important, dimensions. By contrast, I suggest that the concerns shaping what was discussed as a nationwide crisis revealed a debate about political representation and statehood. The authorities' struggle to respond adequately to migration movements - by processing applications swiftly, providing accommodation, and pursuing relevant integration projects - revealed in stark ways the effects of austerity measures and of the privatisation of state services, including public housing, as well as the aftereffects of decade-long disinterest in, and often hostility to, the political participation and social inclusion of minority communities in Germany (Bade 2007, 2013a; Herbert 2001; Klärner 2001; Nökel 2002; Pagenstecher 2008). Chancellor Gerhard Schröder had first pursued rigid budget cuts and reduced state spending on welfare - called Sparpolitik in German, or 'policy of savings' - in the early 2000s. His policy produced lasting divisions in the social democratic SPD party, as well as across German society, even though some have credited the reforms with rendering Germany more economically competitive (Braunthal 2003; Camerra-Rowe 2004; Hassel and Schiller 2010; Hegelich et al. 2011). The harsher English equivalent of Sparpolitik, 'austerity', is rarely used in German discourse. This might explain why German pundits and politicians are more at ease with the supposedly virtuous requirement of living within one's means than other Europeans (The Economist 2015). Nonetheless, in Germany and beyond, austerity and Sparpolitik have been criticised as economically ineffective and politically problematic (Blyth 2013; Schui 2014), with negative consequences for community cohesion and livelihoods. Such effects are particularly brutal when they coincide with economic decline - as happened in Europe in the wake of the 2008 financial crisis and subsequent recession (Clark and Heath 2014; Elgenius 2017).

With governments under pressure to reduce public debt, cuts to public spending and state welfare intensified, particularly in the UK, Ireland, and countries of Southern Europe, suffering from high sovereign debt levels that produced increasingly unstable lives (Stewart and Knight 2016). In response, protest movements and anti-austerity political action became prominent across countries, testifying to discontent in the face of state withdrawal, growing poverty, and inequality. Anti-austerity action mobilised citizens demanding a different economic system as well as more grassroots political involvement and democratic representation (Della Porta 2015; Graeber 2008, 2012; Haiven and Khasnabish 2014). Beyond the social suffering endured by those living under austerity, on the one hand, and global protest movements, on the other, the struggle, or unwillingness, of state institutions to support communities and individuals under pressure had complex social consequences. While some research has suggested that economically difficult times can entail a decline in civic engagement and voluntarism as a result of dwindling trust and general discouragement (Laurence and Lim 2015; Strauß 2008), others have shown that austerity produces new commitment and can invigorate local social action in particular (Cohen et al. 2017). In response to such arguments, this article suggests that the gaps in public administration that surfaced with the so-called refugee crisis enabled long-ignored 
minority communities, Muslim groups first of all, to become involved and claim a different civic identity as active citizens that contribute visibly to the management of a great challenge. State inadequacy and a lack of official preparedness allowed the performance of political belonging through grassroots action.

At the same time, such claims to participation were also rejected. The arrival of people characterised homogeneously as 'Muslim' foreigners, as well as the emergent civic engagement of minority groups settled in Germany, rekindled debates about German-ness, identity, and belonging. Increasingly, open expressions of hostility to diversity highlighted divisions in a country with a history of violence towards its post-WWII immigrants, foreigners, and refugees (Çakir 2014; Funke 1993, 2015; Loginov 2017). When the arrival of asylum seekers reached unseen dimensions, many people in Germany were still grappling with the presence and political participation of religious or ethnic minority groups, as the success of antimulticulturalism publications - such as Thilo Sarrazin (2010) or Heinz Buschkowsky's (2012) books - and fierce debates illustrated (Bade 2013b; Meng 2015). Negative attitudes to non-white or Muslim minorities remained prevalent particularly in East Germany (Heinemann and Schubarth 1992; Locke 2014; Panayi 1994; Schmid 2015), where the populist far-right alternative for Germany (AfD) party emerged with unexpected success to oppose what was seen as a mainstream political party consensus on immigration and pluralism (Bebnowski 2015; Häusler 2016) - a consensus that was surprisingly championed by a conservative Chancellor, Angela Merkel. My conclusions are based on 12 months of ethnographic fieldwork in Berlin, in 2015/2016. I followed policymakers, civil society groups, and protest movements. This article examines responses that illuminate developments across Germany, and particularly the ways in which Angela Merkel became a contested figure in the so-called refugee crisis. I suggest that this was not a result of her actual political power, which cannot be the focus of this article, but stemmed from how she was perceived: as the enabler of a different kind of German society. ${ }^{3}$

\section{Centrist Politics}

Angela Merkel took office in 2005. She was initially Chancellor of a grand coalition, combining the main centre-right and centre-left parties: the CDU, the CSU, and the SPD. Her majority was staggering: 448 out of 614 MPs formed the government coalition. Following the 2009 elections, Merkel changed her coalition partner. The market-liberal Free Democrats (FDP) joined her conservative Christian Democratic Union and its Bavarian sister party, CSU, for 4 years, only to be eventually replaced again by the social democratic SPD after the 2013 elections, with Merkel still at the helm of government. Between 2005 and 2017, grand coalition centrism dominated German politics. Even when the SPD was not part of the government, 2009-2013, it struggled to attack Merkel from the left, since the Chancellor adopted various progressive policies (Schmidt 2015). Journalists even talked about 'the socialdemocratisation of the Union' (Caspari 2012) and accused Merkel of 'stealing' SPD content

\footnotetext{
${ }_{3}^{3}$ Throughout her time in office, Merkel's power was subject to extensive checks and balances, which rarely feature in critical accounts of her supposed European-wide dominance. Her party's conservative wing put pressure on her, as did coalition partners, the Bavarian CSU in particular. Furthermore, German federalism restricts the power of the Chancellor in favour of devolution to regional levels-state governors (Ministerpräsidenten) and state parliaments (Länderparlamente) are important authorities. Regional governments can block or amend federal legislation in the second chamber, the Bundesrat (federal council).
} 
whenever polls showed it to be popular (Seils 2013): army conscription was suspended in 2011 , for example, despite discontent among conservatives ${ }^{4}$; following the Fukushima disaster, Merkel made sure her coalition voted to phase out nuclear power and invest in renewable energies; the cabinet expanded child day-care to allow more women to work, alongside paternity-leave schemes, challenging traditional family models; prominent CDU politicians endorsed a minimum wage - a social democratic demand. Merkel modernised her party, promoting progressive allies and removing opponents (Resing 2013). Some pundits suggested that the CDU was becoming a mere 'chancellor voting club' (Zolleis and Schmid 2014), as pollsters showed that there was little alternative: the CDU could not retain its dominance without appealing to the increasingly post-ideological centre, even if this entailed disappointing traditionally conservative-minded supporters (Jung 2016; Jung et al. 2014). At the same time as Ulrich Beck accused Merkel of domineering, de-politicisation, and harshness with European partner states, socially conservative voters regarded her increasingly as too social democratic, too progressive, and too liberal.

When the refugee situation in the Middle East and the Mediterranean became pressing, Merkel appeared rational and hesitant. In July 2015, she met schoolchildren in the northern port city of Rostock. Among them was a 14-year-old girl, Reem Sahwil. Born and raised in a Palestinian refugee camp in Lebanon, she and her family had come to Germany as asylum seekers 4 years previously. Reem spoke excellent German and asked the Chancellor why she and her family had to live with permanent uncertainty. Fighting to stay in Germany, they faced the constant threat of deportation. Merkel acknowledged that the situation was stressful and unfair on those desiring clarity and promised to accelerate bureaucratic decision-making processes. However, the Chancellor also remained firm and explained that Lebanon was not considered an unsafe country of origin:

Politics is also tough business sometimes. Seeing you here in front of me, you are a very pleasant person, but in the Palestinian refugee camps in Lebanon, there are thousands of people. It we tell them, and if we tell everyone in Africa, that they can come here, then we won't be able to cope. This is a conundrum for us, and so we say: let us make sure it does not take too long to reach a final decision. But some people will have to go back again, too.

A few minutes later, Reem was in tears. Merkel walked across the room to comfort her clumsily: 'I know it is a difficult situation, and I just want to stroke you briefly because we don't want to put you into such a situation.' When the footage became public, the Chancellor's reaction was criticised as cold-hearted and stiff. A new hash tag \#merkelstreichelt ('Merkel strokes') mocked her awkwardness as a witness to tragedy. Attacks on Merkel were accompanied by criticism of her inaction towards refugee suffering at Europe's doorstep. ${ }^{5}$ Later that summer, the growing number of asylum seekers arriving in Germany — as well as the images of drowned children - put further pressure on the Chancellor to abandon her characteristic procrastination when facing high-pressure crises.

\footnotetext{
${ }^{4}$ The suspension of subscription for young German men remained a contentious topic. In the wake of Russian aggression in Eastern Europe, and when refugees illustrated that Germany struggled to control its borders effectively, debates about an end to the suspension took place, but the suspension remained eventually.

${ }^{5}$ There were also others, however, who defended the chancellor and her honest response, suggesting that reacting properly in such a situation is almost impossible for a politician, who can either answer frankly and face accusations of indifference, or promise a solution and end up accused of favouritism or dishonest publicity.
} 
In August, in the East German town of Heidenau, far-right groups, including neo-Nazis, attacked a makeshift reception centre and clashed with the police throughout the warm summer night. Whereas most politicians, commentators, and civil society leaders denounced violent far-right activism, Merkel did not release a comment. The same politician who would later come under attack for her open-door policy was instead chided for silence towards refugee suffering. An online petition was launched, demanding that Merkel visit shelters to demonstrate solidarity with asylum seekers. The public debate compared the tense situation with the early 1990s, when violent groups, predominantly in East Germany, had firebombed refugee shelters, cheered by hundreds of bystanders; dozens of foreigners had been attacked then, some even killed (Panayi 1994; Wowtscherk 2014). Eventually, Merkel's spokesperson called attacks by rightwing extremists 'disgusting', and labelled support by ordinary citizens for hatred 'shameful'. A few days later, Merkel visited the Heidenau asylum seeker centre, where protesters hurled abuse at her. She was called a 'traitor of the people' (Volksverräter). The violent attacks and the insults renewed a debate about East German extremism and a lack of democratic maturity among the formerly socialist population (Schmid 2015; Quent 2015). A week prior to Merkel's visit in Heidenau, the Interior Ministry had already released a new estimate that 800,000 asylums seekers would reach Germany in 2015, almost four times as many as the previous year. The situation and its implications shifted public attention from Greece. The arrival of hundreds of thousands of foreigners without previous ties to Germany revealed inadequate state management, opened up spaces for visible political engagement, and became a key cause for activists from the left, the right, and minority groups.

\section{A 'Refugee' Crisis?}

A week after her visit to Heidenau, during her annual summer press conference, Merkel uttered the words that came to characterise her approach to the refugee situation: wir schaffen das ('we will cope' or 'we will deliver'). In fact, however, the numbers quickly exposed that public institutions struggled to deliver, particularly judged by their own high standards. At the beginning of 2015, German society had been at ease. Trust in the government to manage Europe's crises had been high: despite uncertainty over Greece, $79 \%$ of Germans were satisfied with their political system (Petersen 2015). At the end of the year, the situation had shifted. Positive attitudes towards the future were falling similarly to the 1970s oil crises and the aftermath of 9/11 (Losse 2015). The apparent failure of state institutions contributed to the decline of trust in the future, but also led to emergent civil society action.

Due to Germany's federal structure, administrative responsibilities are devolved to regional and local levels. Therefore, each of Germany's 16 regions (Länder) is allocated a specific share of asylum seekers, based on a region's population and tax revenues. ${ }^{6}$ Berlin is not just Germany's capital but also one of these regions. It was responsible for managing just over $5 \%$ of asylum seekers in 2015/2016, guiding them through their application procedures with the National Agency for Migration and Refugees (Bundesamt für Migration und Flüchtlinge, BAMF). Berlin's Regional Agency for Health and Social Affairs - usually referred to by its acronym, Lageso (Landesamt für Gesundheit und Soziales)—was tasked with the registration

\footnotetext{
${ }^{6}$ This complicated quota and distribution mechanism is based on the Königssteiner Schlüssel document, which is updated annually and regulates contributions made by individual regions for projects with national funding.
} 
and management of asylum seekers in the city. Soon, however, Lageso became a nationwide symbol of failing public institutions. Outside its unassuming office block in Berlin's central Moabit district, hundreds, often thousands, of asylum seekers queued for hours. Many left in the evening without having spoken to an advisor and missing appointments, while Berlin's administrative districts and the Senate accused one another of mismanagement. When I spoke to Lageso employees, one admitted that they were totally overwhelmed; the Agency was understaffed and mismanaged, she reported, and files were sent back and forth between offices without a purpose, often lost on the way, as asylum seekers squeezed into the narrow corridors of the postwar high-rise. The situation appalled the public, shocked by reports of security staff violence and the disappearance of a 4-year-old child from Lageso, where his mother waited for an appointment. The boy was abducted, sexually abused, and killed by a German paedophile, who was arrested outside Berlin.

In late October 2015, when hundreds of asylum seekers arrived in the city every day, I visited a makeshift camp outside Lageso. Hundreds of people were forced to spend the night here. The authorities did not manage to distribute enough hostel vouchers or allocate shelter places. Hours before Lageso opened each morning, queues formed at the gate. A voluntary association called Moabit Hilft! (Moabit Helps!) achieved national recognition for coordinating support activities, distributing food and water, arranging accommodation for hardship cases, and accompanying applicants to appointments. Moabit Helps! volunteers were regular commentators on news programmes and talk shows. They denounced Berlin's failing public administration, and exposed volunteer frustration and exhaustion. When the mayor invited the initiative to an award ceremony in the city hall, Moabit Hilft! declined and explained the decision in a Facebook post:

It is not just that we can't fit the event in our schedule, because, at that time of day, we hand out meals, move people into busses, greet newcomers and so on. We also find this invitation, at this point, tasteless and bigoted. We don't see any of 'the Senate is doing what it can to welcome newcomers, caring for them and facilitating integration'. Otherwise there would not have been people standing in the rain and mud this morning. We don't want to listen to a 'choir of encounter' [during the ceremony in the city hall] while people are without provisions at Lageso. We will not be patient. The responsible senator is accusing us of impatience anyway - instead, you should thank the refugees for their 'patience'.

On 26 November, the New York Times published an article on 'the chaotic reception in Berlin', detailing how 'a country known for its efficiency' struggled to 'impose order on the tumultuous wave of humanity arriving at its border daily'. The authors highlighted that Berlin's politicians had contributed to the chaotic situation, since:

For two decades, Germany has sought to streamline its government, and nowhere has this been more visible than in Berlin. After the East and West sectors of the city were fused in 1990, its public work force was at 200,000. The city set out to halve that number, spinning off some services and downgrading others, so that by 2004 , the number of employees had shrunk to 149,000 . Even as the population grew, the number of city employees continued to drop. A decade later, there were just 117,000 of them, and those who remained complained that their ranks were too thin to provide needed social services to Berliners. (Eddy and Johannsen 2015)

They conclude with a quote from a volunteer: "“This is not a refugee crisis," she said. "This is an administration crisis." For over a decade, civil society actors and leftwing politicians had 
denounced cuts to social services, public housing, the police, schools, and local administration. There was German resistance to austerity at home. Now, merely weeks after Merkel had promised that 'we will manage', the insufficient preparation of public institutions was unmistakeable. Such questions of state preparedness and capacities in the face of critical developments became more pressing in January 2016. Hundreds of women reported having been molested, some raped, by mobs of 'foreigners' during public New Year's Eve celebrations in Cologne. The police admitted that they had been understaffed and unable to control the situation, ceding an extra-legal space in the heart of one of Germany's largest cities. Shortly after, a well-known feminist writer, Alice Schwarzer-who is also an outspoken critic of supposedly Islam-inspired patriarchy_-published Der Schock-Die Silvesternacht von Köln (Schwarzer 2016) (The Shock-New Year's Eve in Cologne). Contributors condemned misguided tolerance of Islamic chauvinism and sexual depravity. The events and coverage of New Year's Eve in Cologne led to what some observers called a 'moral panic' (Kosnick 2018). But did the night constitute the watershed moment that turned Germans against foreigners? In February 2016, a Deutschlandtrend survey showed that $81 \%$ of respondents did not think the government was managing the refugee situation well. Angela Merkel's approval ratings had dropped to $46 \%$. Sixty-three per cent of Germans now favoured an upper limit on the numbers of refugees the country would accept each year; $33 \%$ rejected the cap. At the same time, $94 \%$ of respondents wanted Germany to continue to receive people fleeing war or civil war, $73 \%$ agreed to extend protection to those suffering from political or religious persecution, and $25 \%$ even said that Germany should offer asylum to economic refugees (http://www.infratest-dimap.de/umfragen-analysen/bundesweit/arddeutschlandtrend/2016/februar/). The results suggested that a large majority backed assistance for people fleeing conflict and persecution, despite hysterical media coverage over New Year's Eve in Cologne. The public, however, also expected more order in the process. Back in Berlin, this was still missing.

'I will take absolutely everything. Look, I get a call in the evening and someone tells me the number of people who will arrive here the next morning. I need to find a place for all of them, sometimes 400, sometimes 800, sometimes 1,000.' Michael Müller, the mayor of Berlin, was controlled and determined as he addressed an audience of local residents in the district parliament of Berlin-Neukölln in November 2015. One Berliner had accused Müller of a lack of leadership, citing Moabit Hilft! as proof that public institutions had surrendered to crisis and chaos. He had also rejected Müller's plan to use hangars in the disused Tempelhof Airport as temporary emergency shelters. Müller replied in clear terms: he had no choice. Tempelhof Airport became a key site of contestation in Berlin's refugee crisis (Muehlebach 2016). Inaugurated in 1941, the enormous structure was once the world's largest building. Hedged in by living quarters in what became isolated West Berlin, the airfield was vital for the city's survival during Stalin's 1948/1949 blockade. After reunification, however, its short runways made Tempelhof unattractive for commercial aviation and larger planes. Airlines moved to other airports. Tempelhof closed in 2008. Its gigantic hangars have hosted fashion shows and film productions but remained mostly unused. The airfield with two landing strips has become a public park, used by runners, cyclists, and hipsters from gentrifying neighbourhoods nearby. In 2014, a public referendum instructed the Senate to keep the field open to the public and terminate negotiations with private property developers (Figs. 1 and 2).

When the number of asylum seekers rose sharply, Berlin's districts converted dozens of school gyms into emergency reception centres, with mattresses, duvets, and portable canteens. As sports clubs had to suspend their activities and school lessons were cancelled, the 
Fig. 1 'Müller's revenge'.

Leftwing protest sticker against a 'refugee ghetto' on the Tempelhof airfield - a project favoured by the mayor of Berlin, Michael Müller
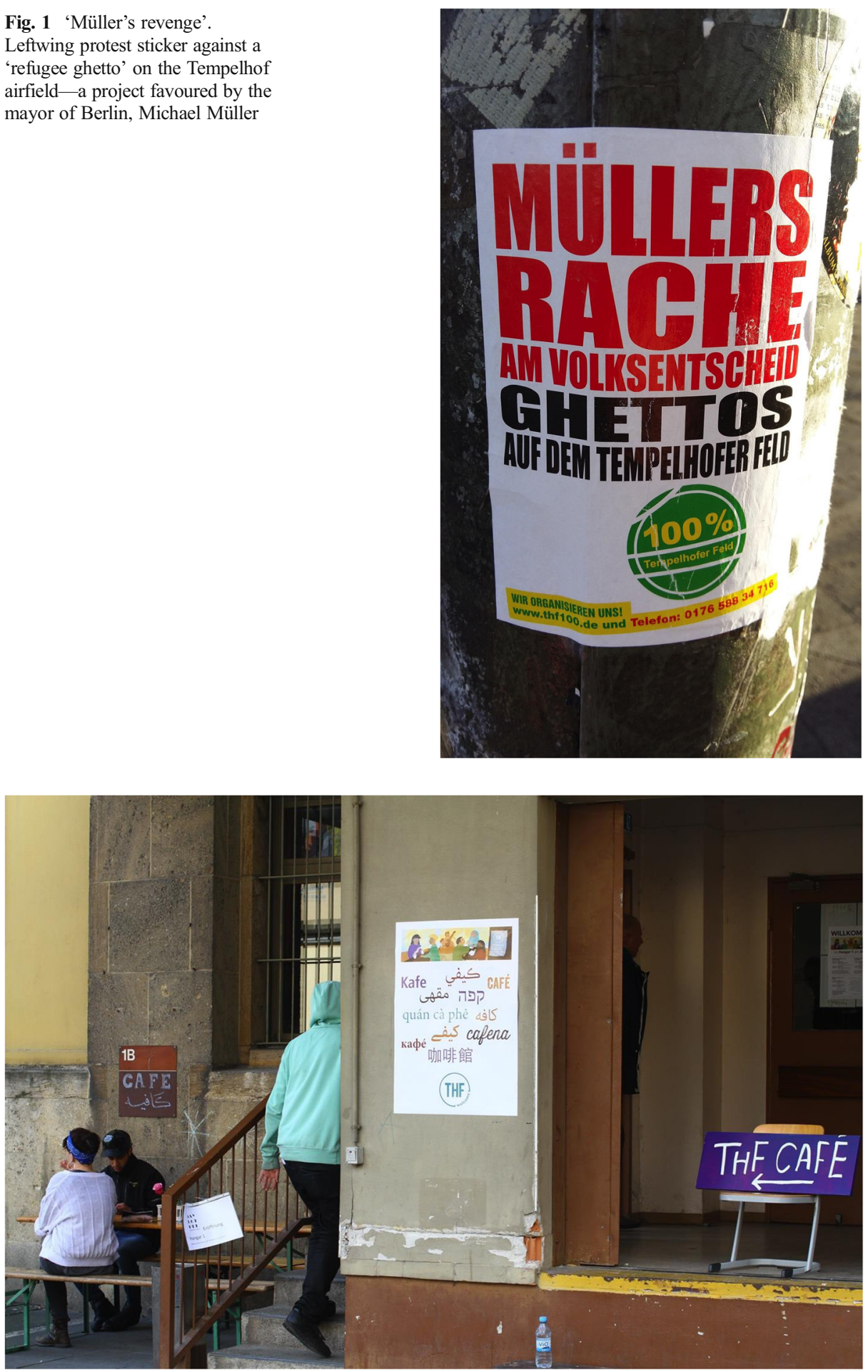

Fig. 2 THF Welcome café. Grassroots support group for asylum seekers living inside the disused airport hangars 
expanding infrastructure of emergency impacted on city life. Disused buildings were turned into accommodation, including office blocks, seats of the district administration, and department stores. It was only a matter of time until the mayor would consider Berlin's largest, and empty, public structure: Tempelhof Airport. Before the end of 2015, a few thousand asylum seekers had moved into tents inside the hangars. The Senate planned an asylum seeker village for 8000 people, complete with schools, bathrooms, and canteens in temporary structures on the airfield aprons. A volunteer initiative, THF Welcome, was founded to facilitate encounters between residents and refugees, collect donations, and offer German lessons. The decision divided. The grassroots initiative 100\% Tempelhofer Feld, which had organised the referendum to prevent private property development on the airfield, saw the emergency rhetoric as an attempt to legalise construction by stealth and undermine the public vote. The left-leaning initiative considered the Senate's connection between the refugee situation and construction plans as intentionally divisive, casting $100 \%$ Tempelhofer Feld as hostile to asylum seekers. The initiative denounced the Senate's plans as a 'refugee ghetto', isolated from urban neighbourhoods, and demanded the temporary requisitioning of empty luxury properties to accommodate newcomers. After years of austerity politics, cuts to public funding and welfare services, and the privatisation of social housing, trust in Berlin's Senate to pursue social policies was low. During a crisis popularly associated with the arrival of different cultures, it was actually the legacy of austerity that necessitated emergency measures and led to political conflict in the face of struggling public administration.

\section{Emergent Engagement}

Angela Merkel had moved her conservative CDU party to the political centre by adopting progressive policies, frustrating ideologically minded citizens from the left and right. ${ }^{7}$ Her calm manner and Germany's comfortable economic situation brought high approval. In August 2013, just before her second re-election, $81 \%$ of Germans found Merkel competent, $79 \%$ considered her a strong leader, and $65 \%$ said she was credible (http://www.infratestdimap.de/umfragen-analysen/bundesweit/ard-deutschlandtrend/2013/august/). One year later, $59 \%$ were content with the grand coalition government - the highest figure that pollster ever recorded - and 74\% were satisfied or very satisfied with Merkel (http://www.infratest-dimap. de/umfragen-analysen/bundesweit/ard-deutschlandtrend/2014/august/). In turbulent times, with crisis talk pervasive, a large majority appreciated her stable and calm leadership. Neither critics from the left, demanding solidarity with crisis countries and the end of austerity, nor from the right, dissatisfied with rescue packages and the modernisation of a conservative party, could challenge her popular centrism.

Then, however, the refugee situation illustrated that not all was well in Germany: state institutions struggled and revealed the inadequacy of public institutions after years of cuts. At the Austrian border, the authorities could no longer register the newcomers. Coaches drove them to makeshift facilities across the country. Many asylum seekers were dissatisfied with the towns or villages to which they were allocated and left on their own account, overlooked by the chaotic administration. In February 2016, the Interior Ministry admitted that 130,000 asylum seekers and refugees were no longer at their designated shelters. They had disappeared,

\footnotetext{
${ }^{7}$ Merkel became CDU party head in 2000, and did not surrender this position during her chancellorship, which strengthened her programmatic leadership within the CDU.
} 
with possible reasons being onwards travel, return journeys, multiple and faulty registrations, or illegality. Merkel had initially faced criticism for inaction, exemplified by her encounter with Reem Sahwil and silence on rightwing violence. Soon after, however, when the government changed its course on refugees and accepted responsibility for protection, the authorities could not keep Merkel's promise that 'we will manage'. Moabit Hilft! or THF Welcome were two of thousands of similar initiatives that were established in response to new emergency shelters in neighbourhoods, towns, or villages. Between 800,000 and one million Germans joined such voluntary groups (Schiffauer 2018). The media coined the unprecedented civil society response Willkommenskultur, a warm culture of hospitality. At train stations, volunteers greeted asylum seekers with toys and donations. Large numbers who wanted to teach German, support integration, or adopt unaccompanied minors overwhelmed church volunteer projects. According to Naika Foroutan, a Berlin-based sociologist, Merkel's centrism shaped the enthusiastic civil society response:

There is certain saturation across Germany. Many see the Merkel years as stagnation. The refugee situation offers a chance to break out of this routine. My colleagues Serhat Karakayali and Olaf Kleist documented the motivations of volunteers in a study. Respondents said they didn't simply get involved to improve the humanitarian situation of the refugees - but 'to shape society'. (Foroutan 2015, p. 33)

Foroutan cited a survey regarding the motivation of volunteers in refugee support initiatives, conducted before the numbers peaked in 2015, in which $74 \%$ of volunteers had stated that they wanted 'to shape society' with their engagement (Karakayali and Kleist 2015, p. 33). Even though the survey's multiple-choice option did not require a clear concept of social engagement, the high figure illustrates a desire to connect one's involvement with a notion of virtuous and active citizenship. ${ }^{8}$ The study was followed up with more participants 1 year later, at the height of what was now called a refugee crisis. Two thirds of the respondents had only joined initiatives in 2015, and the authors suggested that, over the course of that year, refugee support had moved from being a leftwing fringe activity into the social mainstream. An even greater share of $96.8 \%$ of volunteers now stated that they wanted to 'shape society' in some way, which illustrated that 'the political aspect of volunteer work for refugees is a crucial factor for engagement' (Karakayali and Kleist 2016, p. 33). The apparent lack of state planning and personnel created a space for others to become involved and break out the centrist 'stagnation' (Foroutan 2015). One important group that sought to occupy these spaces were Germany's minorities, particularly Muslims. Politicians considered them crucial mediators who could explain 'German culture' and to asylum seekers and refugees.

Aiman Mazyek is the head of the Central Muslim Council in Germany (Zentralrat der Muslime in Deutschland). The organisation represents around 300 predominantly Arab Muslim communities and their 10,000 members. Even though the Council is smaller than its Turkish counterparts in Germany, its charismatic chairman gave the organisation a high public profile. He was invited to talk shows and gave numerous interviews. Mazyek encouraged Muslims to be more involved and praised Islamic communities that assisted newcomers with integration efforts. Mazyek used the crisis situation and calls for Muslim civil society to position Germany minorities as dedicated and reliable helpers, seeking to build trust in the ability to live together in a pluralist country and confront challenges collectively. In January 2016, Mazyek spoke to me about the engagement of Muslim groups:

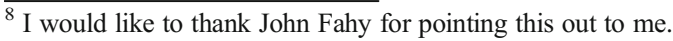


2015 changed life for Muslims in Germany. Public offices and institutions now regularly involve Muslim associations for projects ranging from radicalisation prevention to welfare and integration. There is more cooperation, even though it's still not enough. But there have been some important developments. However, there is also a new debate on religious faith and whether or not it prevents integration. The atheist 1968 generation is still saying that religion is all nonsense anyway. But then I say this: we have over 1,000 volunteers across our communities; 500 families have offered to be legal guardians for unaccompanied minors; over 40 communities have free German classes; and dozens of mosques provide accommodation and other assistance. We also have 150 doctors volunteering in refugee shelters. 90 of our associated communities have recently doubled their membership because of asylum seekers and refugees.

The inadequacy of public institutions permitted new actors to perform ethical kinds of active citizenship: Mazyek presented Germany's Muslim minorities as trustworthy, reliable, and virtuous members of German society, confronting those who questioned their belonging and integration success. By supporting state institutions, such groups used heightened attention to demonstrate their progress with 'integration', showcase their interest in political participation, and confront Islamophobia and processes of exclusion.

\section{German Muslims and Civil Society}

At the edge of the Tempelhof Airfield, one of Germany's most spectacular mosques was opened in 2005. The impressive building in historicising Ottoman architecture, complete with two minarets, was funded by DITIB, an association that oversees over 900 Turkish mosque communities across Germany. DITIB is under Turkish government authority to support and oversee cultural practices abroad. In the 1960s, when millions of Turkish men came to Germany as 'guest workers' (Gastarbeiter) to staff the country's factories, they were little concerned with public visibility: their Turkish culture clubs or prayer rooms were usually disused shops or garages, often in inconspicuous backyards and hidden from view. ${ }^{9}$ Berlin's Sehitlik mosque (Fig. 3), however, signals the growing confidence of Turkish and Arab minorities. Since Muslim communities do not have the same legal status as Christian or Jewish faith groups, the mosque is officially registered as a Verein, an association or club. At the height of the refugee crisis, Ender Cetin - a youthful and enthusiastic Berliner with Turkish parents - was the head of the Sehitlik Verein. When I spoke to him in September 2015, he proudly listed a string of refugee-support activities:

We are in contact with emergency shelters across the city. We collect donations and deliver them. We have doctors, paediatricians, and medical students among our members, who are always on call to help out in shelters. We have Arabic-speakers in our community who teach German and translate. Many mosques look after asylum seekers who missed Lageso appointments because of long queues. Friday evening, when the Agency closes, many asylum seekers don't know where to go. We find places for them to stay. We also inform the authorities about Muslim needs. In many shelters, halal food isn't available and there are no prayer rooms. Our youth organisation has developed a

\footnotetext{
${ }^{9}$ For an overview of how desires for low visibility and often intentional exclusion from certain public realms shaped the initial decades of Turkish migrant life in Germany, see Mandel (2008).
} 


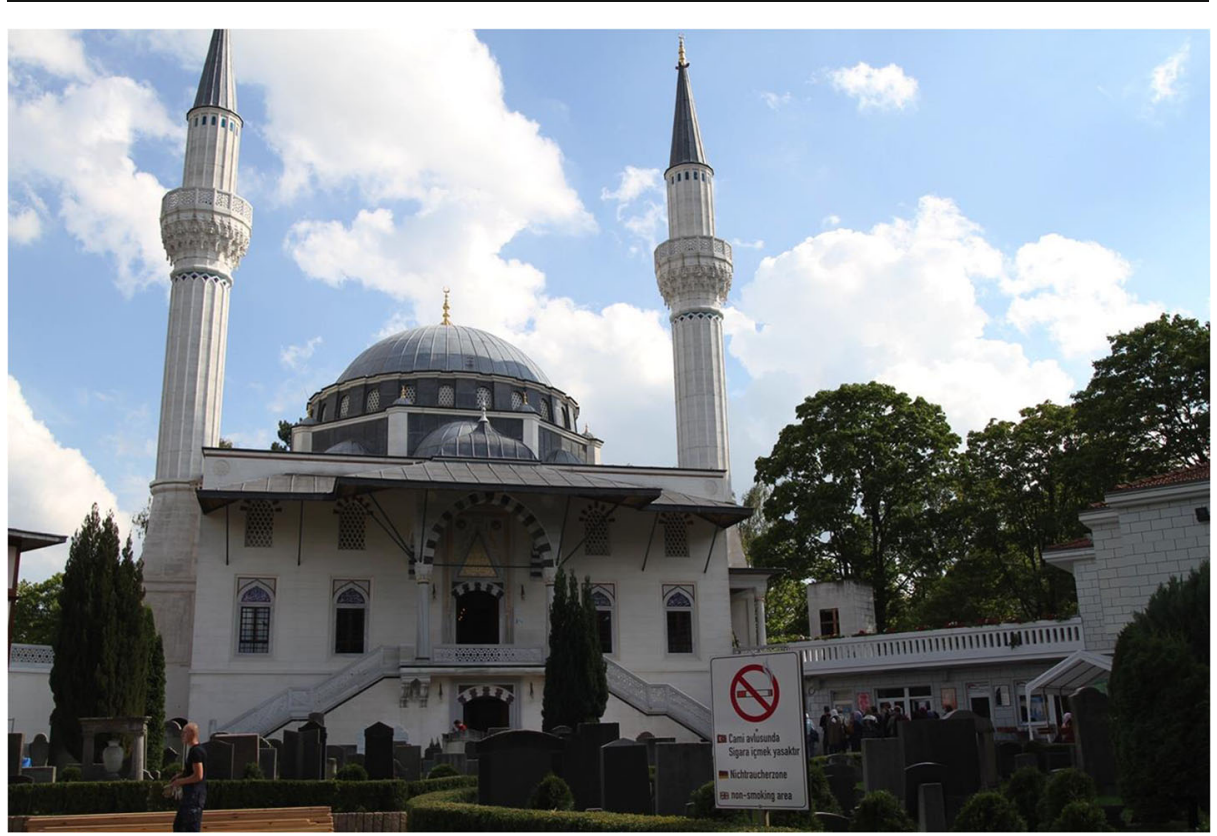

Fig. 3 Sehitlik Mosque, Berlin

sponsorship scheme: they 'adopt' asylum seekers, meet regularly, help with language learning, accompany them to official appointments, and show them the city. Mosque communities organise Islamic festivals and celebrations to involve newcomers and connect them with local people (Fig. 4).

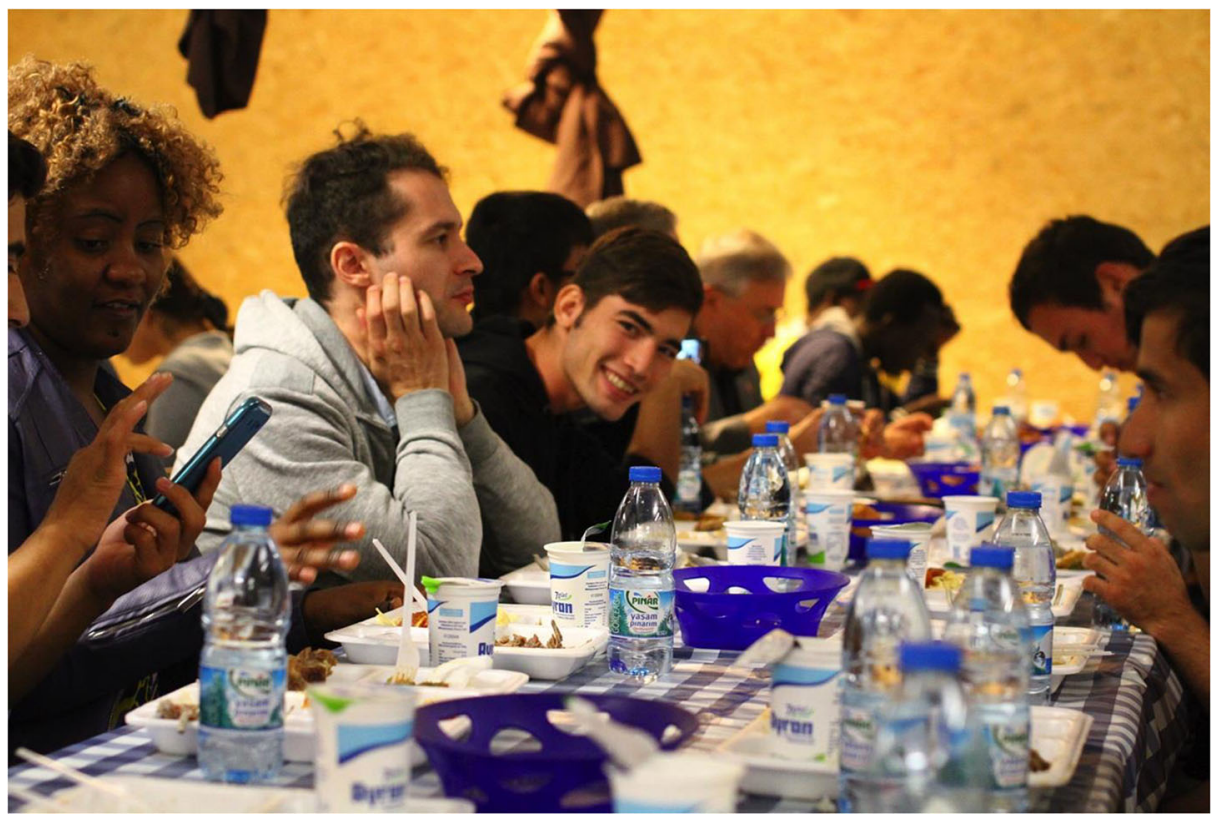

Fig. 4 Eid celebration for asylum seekers and other newcomers in the Sehitlik Mosque 
Cetin was eager to demonstrate that his community was proactively supporting state authorities during a struggle of public administration. At the same time, he underlined that the Sehitlik had been a relevant civil society actor before. He lamented a lack of official recognition for the mosque's social work:

We have tried to reach out to the city. After 9/11, many Muslims realised that they had to open up. They could no longer live in homogeneous, secluded communities. Ten years ago, we started mosque tours. We invite school classes, church groups, or police teams to learn more about Muslim life. We organise workshops and seminars about German Islam. We host interfaith events, support refugees, and want to be involved with the neighbourhood. The large building helps. It gets people's attention. If it were some backyard room, we wouldn't be able to attract so many people. If people think of Turks in Berlin, they think of the Sehitlik mosque. But there are still problems. We aren't on the same level as Christian churches, so we don't get state funding. We need to apply to external sources. Often, when we apply for funding for religious activities, we are told that we are doing social work. But when we apply for funding for social work, we are told that are a religious group. With the refugee situation, we can show that we contribute to German society. Many visitors on our mosque tours have asked us: 'so what are you doing for your fellow Muslims coming to Germany today?' Or they wonder whether we are happy that more Muslims are coming here. I don't think anyone in our community has thought this: more Muslims, great! Asylum seekers remind us of the stories our parents told us: they would have needed support when they arrived in Germany. Now, we are here, and we can do something for the newcomers. There is a great desire to help among German Muslims.

Cetin connected the fate of asylum seekers with the family biographies of Turkish Germans. He hoped that Muslim minorities could now demonstrate their importance for German society, and perhaps also improve the financial circumstances for non-Christian faiths. At the end of September, I attended the Eid al-Adha festival at the mosque. A large yellow banner wished a blessed day in different languages. Stretching from the main building to a teahouse, trestle tables were heaving under the weight of donations: trousers, shoes, jackets, prayer rugs, and copies of the Quran. Non-Muslim volunteers helped out, many wearing 'refugees welcome' buttons. Others prepared halal lunch in the mosque basement. Members of the Sehitlik youth team were shuttling asylum seekers from shelters across the city to the event. 'Hello, my name is Ender Cetin, and I am the chairman of this mosque', Cetin addressed a crowd of 100 people in English, simultaneously translated into Arabic by another member of the Sehitlik committee. He welcomed the newcomers to the Islamic prayer house, and encouraged them to visit any time in the future. As he told me shortly after his address, Cetin was excited about the opportunity, but also disappointed by the turnout: a large number of similar events across the city meant that fewer than the 300 people expected had arrived. Camera teams and journalists followed Cetin, community members, and newcomers to lunch. Afterwards, inside the opulent Sehitlik prayer room, the Turkish consul general, Ahmet Basar Sen, addressed the guests. He spoke in German and was translated into Arabic:

As a diplomat, I have lived in many countries. I know how difficult it is to settle into another culture. But there are many people like you in Berlin. They came to this city for work, and their families followed. They turned Berlin into their home. Berlin's Turks extend to you a warm welcome and offer support. They have already built the 
infrastructure you need to live well here. They can help you with the first steps. Mosques offer German classes. After you have found accommodation and can support yourself, learning the language is the most important thing for adults and children. In this country, the language is German. Most Turks speak German fluently here - it is possible. Only the language will open up a new world for you and allow you to talk about your skills and find a job. And a word of warning: there are dangers in every country. Radical Islamism is one of them here. There are people who want to abuse and exploit our children for their wars. We need to be wary and cautious, particularly during the first months, when young people speak little German. These guys speak Arabic and promise appreciation and purpose in life. We need to fight them. The Turkish community has always shown the friendly face of Islam here in Germany.

In his speech, Basar Sen underlined that the newcomers' religious needs provided Germany's Muslims with an opportunity to shape civil society responses. Importantly, the diplomat was not simply addressing refugees: various journalists followed the event. His German-language address aimed as much at a German audience as asylum seekers. Basar Sen performed an assurance for German citizens that minorities with Turkish roots were eager to help with the refugee challenge. Their cultural knowledge was portrayed as an important asset, rather than as a danger for German society - by which he addressed growing anti-Muslim populist rhetoric. Furthermore, Basar Sen highlighted the importance of employment for integration, since the ability to contribute through work plays an important role in German discourses about integration. Furthermore, the Turkish official reiterated that radical Islam is not just a threat to Westerners, but also to most Muslims. With the appearance of large numbers of refugees and the crisis in public administration to manage their presence, Muslims were not simply able to perform relevance as civil society actors, but also sought to reposition themselves as trustworthy partners that shared German values as well as anxieties of violent Islamism, preaching the importance of language learning, work, for integration. This article cannot assess conclusively to what extent such efforts to achieve recognition for minority engagement were successful - also because the situation is, at the time of of publication (2018), not settled. What matters is the attempt of minority communities to use the state struggle to make a claim on political belonging as citizens through public activities. What was popularly discussed as a crisis situation constituted by the arrival of Muslim asylum seekers, and in fact revealed the inadequate preparedness of austerity-hit public institutions, also enabled emergent forms of engagement and claims to inclusion and recognition.

After the Islamic festival, I wandered across to the Tempelhof Airfield, where secular support initiatives hosted a welcome picnic (Fig. 5). Bands were playing on stage, surrounded by food and drinks stalls. Civil society groups talked about their activities and recruited volunteers. Signs encouraged participants to download a mobile phone app that matched guests according to language skills and interests. At one stall, I spoke to Franziska, a 22-year-old German, who was studying literature at Berlin's Humboldt University. She was handing out flyers for free German classes and explained her initiative, Berlin Next Door:

We connect Germans with refugees in shelters. There is no state infrastructure for this; it's all over the place. Many refugees are lost. We ask people which languages they speak and match them. We want both sides to be able to get to know different cultures, to learn about each other. They'll all live together here in the future, so they should know one another. 


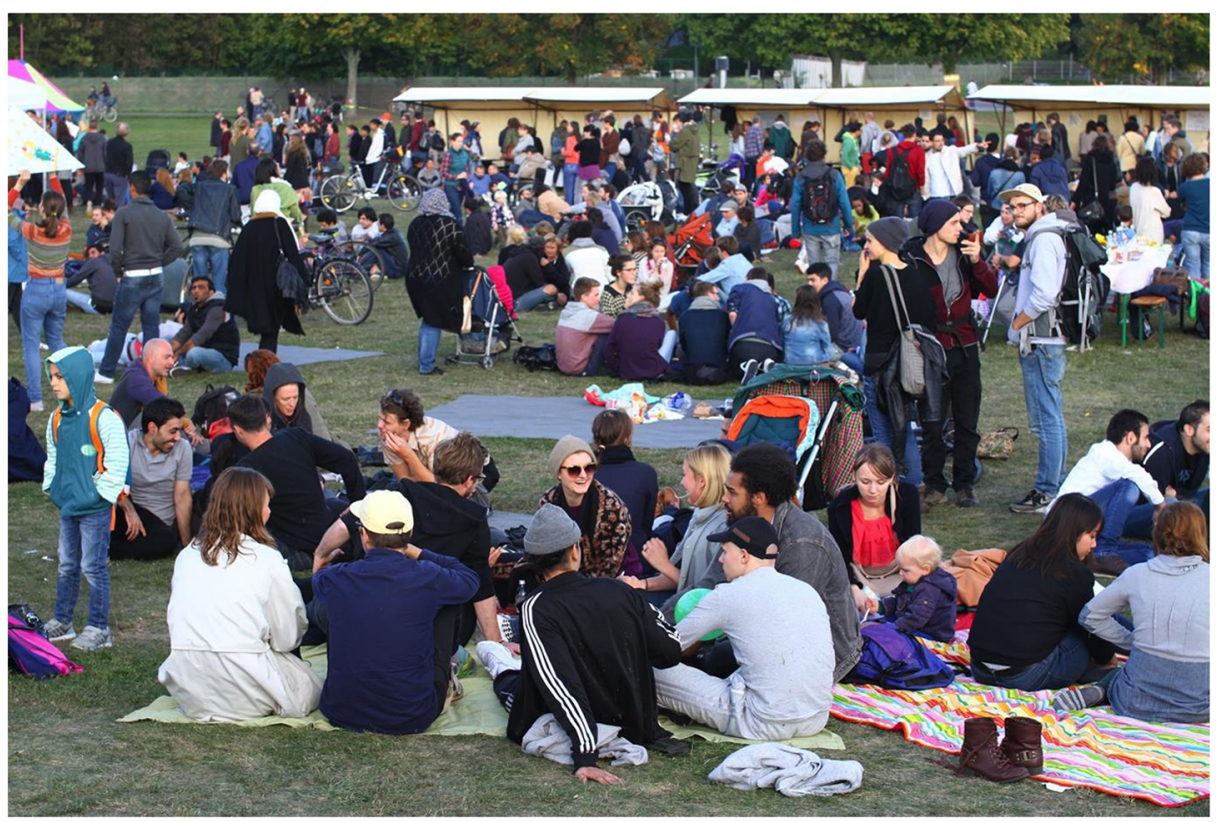

Fig. 5 Welcome picnic on Tempelhof Airfield, Berlin

She told me that she had not been involved in similar activities before, but the current situation and the struggle of state institutions had presented her with an important opportunity to reflect on the situation and pursue a new ethics of engagement:

I'm a student and I've had a privileged life in Germany, but my country hasn't behaved well towards minorities. Refugees have been drowning in the Mediterranean Sea for years. And what has our government done? Nothing. Young people need to get involved and show that we are different. I don't want the newcomers to live in mono-cultural ghettos (Parallelgesellschaften). I want them to understand our lives. We'll have a new culture here in the future, with all the newcomers. I want to influence that.

Franziska connected anger at political passivity in the face of suffering with an aspiration to influence an increasingly diverse society. Hundreds of likeminded people joined the picnic. I attended dozens of similar events with enthusiastic volunteers, young and old, who used the spaces opened up by state failure to become involved and 'shape society' in different ways. The second half of 2015 was dominated by exciting, creative initiatives, which did not only emerge in large cities, but across the country. In the towns and villages I visited, civic engagement was as enthusiastic as in large cities. In addition, new language classes were more commonly established in smaller communities than in large ones - probably since the state infrastructure to teach German as a foreign language was even more sparse in the countryside, and, during the 'refugee crisis', volunteers stepped in to fill the gap (Karakayali and Kleist 2016, p. 16).

\section{The New Right}

Ulrich Beck passed away in January 2015. He did not live to see how the Chancellor he had criticised for being hesitant and passive became an icon of pro-refugee activism. Merkel's 
change of heart drew heavy criticism, but she defended it staunchly. She appeared in talk shows and explained her decision repeatedly. In response, a significant part of disillusioned conservatives judged Merkel's defence of what they saw as uncontrolled and dangerous migration as final proof that the CDU was no longer a properly conservative party. Demand for more traditional political views increased, and an alternative to centrism emerged.

The Alternative for Germany, or AfD, was founded in 2013. Its key objective was opposition to euro rescue packages. Bernd Lucke, one of the party's co-founders and leaders, had taught macroeconomics at Hamburg University until he took a sabbatical for his political career. The party included traditional family values and more national sovereignty in its political programme (Bebnowski 2015), and rejected the use of German public funds to bail out Greece, but without much electoral success. In the 2013 elections, the party missed the $5 \%$ threshold to enter parliament. In the summer of 2015, the AfD polled at around $4 \%$ (http://www.infratest-dimap.de/umfragen-analysen/bundesweit/ard-deutschlandtrend/2015 /august/). With the refugee crisis, however, the party shifted its profile to staunch social conservatism and questions of immigration, Islam, and national identity. Concerns about national security and weak public institutions fused ethnic and cultural issues with questions of safety and statehood. Bernd Lucke became increasingly isolated in a party that moved to the right. He left the AfD in July 2015. In regional elections in 2016, the AfD showed that an antiMerkel and traditionally conservative platform in favour of authoritarian statehood and closed borders could have significant success, particularly in East Germany: in Saxony-Anhalt, 24\% voted the AfD into the regional parliament; in the neighbouring East German region of Mecklenburg-Vorpommern, 21\% chose the party, while Merkel's CDU reached only $19 \%$. And even in West Germany, the party could thrive: in Baden-Württemberg, 15\% voted AfD in March 2016; and in Rhineland-Palatinate, 12\% supported the Alternative. Many traditional conservatives punished the government's unwillingness to stem what was seen as uncontrolled immigration. Merkel's progressiveness had long irked them, but Germany's history made it difficult to establish the equivalent of the far-right political parties that exist in the UK (UKIP), France (Front National), or Italy (Lega Nord). With the refugee situation, the Alternative for Germany emphasised far-right and anti-liberal authoritarianism. As refugee support groups offered a lively alternative to centrist stagnation, shaping society actively and enthusiastically, the AfD provided an alternative for the disappointed right, reaping frustration over the lack of political representation with Merkel's there-is-no-alternative progressive centrism (Fig. 6).

Merkel changed tack in 2016. Under German leadership, the EU struck a deal with Turkey, in effect paying the country to stop asylum seekers from leaving. Austria, Hungary, and other countries along the main route from Greece to central Europe closed their borders. Merkel promised that the events of late 2015 - chaos, state failure, and confusion-would not be repeated, but she continued to defend her decision to support asylum seekers in need of protection. All main parties eventually agreed on the need for a stronger state in the face of domestic and international challenges, promising to invest more in the police, schools, intelligence, public offices, and national security. Merkel, however, remained contested among conservatives. In September 2015, the CDU had polled at $42 \%$, and the AfD at $4 \%$ (http://www.infratest-dimap.de/umfragen-analysen/bundesweit/ard-deutschlandtrend/2015 /september/). Exactly 1 year later, the CDU had dropped to $33 \%$, with the AfD now at $14 \%$; the other parties had remained more or less stable (http://www.infratest-dimap.de/umfragenanalysen/bundesweit/ard-deutschlandtrend/2016/september/). But Merkel remained the uncontested leader of her party and eventually resurged in the polls. Even though her party lost many voters to the AfD, the CDU won the 2017 national elections, and Merkel could 


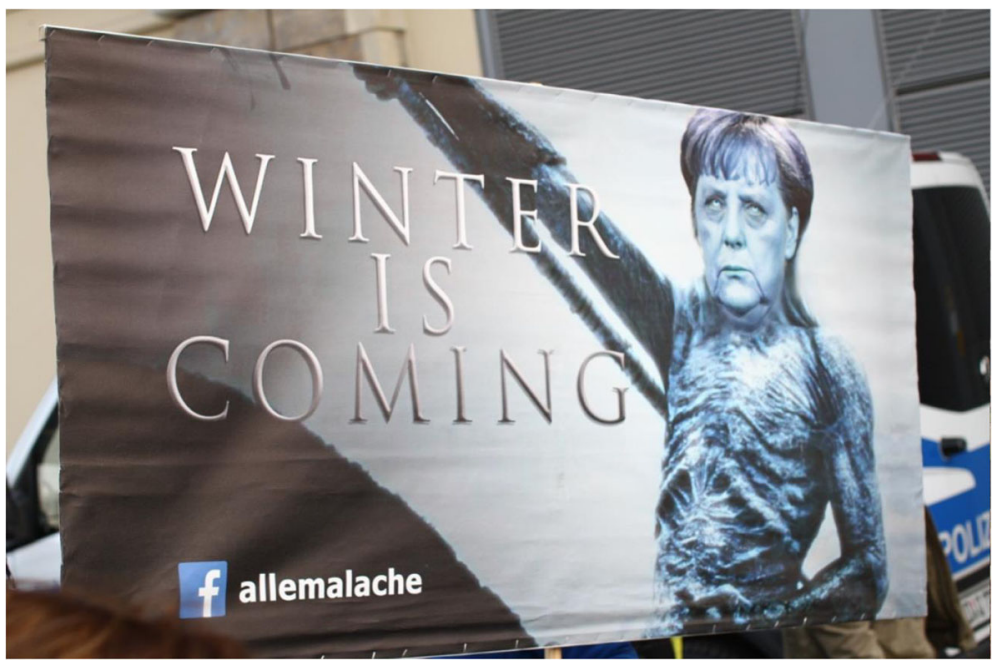

Fig. 6 Anti-Merkel placard at a protest in Dresden, East Germany

claim a fourth term as Chancellor. Arguably, however, her legacy will be shaped by allowing a far-right party to become the third-largest political force in the federal parliament.

\section{Conclusion}

In January 2017, one of Germany's most prominent conservative politicians left the CDU after 30 years of active and outspoken membership. Erika Steinbach had been the MP for a Frankfurt constituency since 1990, but with the party's modernisation, her positions were increasingly peripheral. Steinbach was born in 1943 in Rahmel, a village in present-day Poland. Steinbach's parents were stationed there. When the Red Army marched on Berlin, the German population escaped or was killed. Rahmel ultimately became Rumia, and Polish. The 12 million ethnic Germans expelled from Eastern and Central Europe-including Steinbach's family - faced a cold reception in the East and West German cities, towns, and villages in which they settled (Kossert 2008). Many struggled with displacement. In 1957, the Federation of Expellees (Bund der Vertriebenen) was founded as a lobby group for Germans with a biography of expulsion. Between 1998 and 2014, Steinbach was the Federation's president - a staunchly conservative association, which has been accused of far-right, revisionist tendencies (Jakubowska 2012; Ahonen 2003). When Steinbach leftthe CDU in 1947, she accused Merkel in an open letter of hollowing out conservative values and undermining the rule of law:

With the new government led by a conservative majority in 2005, the political behaviour of the CDU, under chancellor Merkel, has changed in a worrying, even dramatic way. The euro rescue packages, beginning in 2010, unravelled the Stability Pact and were implemented outside legal frameworks. ... The government's abrupt exit from nuclear power in March 2011, within three days of the Fukushima catastrophe, occurred without any legal basis. ... This all was dwarfed by the Chancellor's solitary decision to allow over one million migrants to come to Germany for months without order and control; they were even transported here in buses and trains, even though many came from safe 
countries of origin and via other EU states - according to the law (Dublin Agreement), they should have been repelled. Without the sacrificial engagement of numerous volunteers, our land would have sunk into chaos. The responsible state authorities were - and partly, they are still - struggling with this mass migration. ... With these arrivals, so much is clear because of the horrible attacks, terrorists also came to Germany. National security and our way of life, as previous New Year's Eve celebrations have shown, are under threat. ... Regarding the CDU, I have to note with sadness that while the indispensable conservative element is still part of our party programme - including the preservation of the rule of law -in reality everything has been done to stigmatise this element of CDU policy and to marginalise it gradually. ... I am convinced, and I fear, that political decisions under a party leader and Chancellor Merkel will continue to disregard the long-term welfare of Germany and the rule of law. Instead, they will be based on what is for me an incomprehensible and unsystematic ethos. This means that, after 40 years of CDU membership, I have to say with sorrow in my heart: THIS IS NO LONGER MY PARTY!

Steinbach refused to join the AfD, but backed the Alternative in the 2017 parliamentary elections, where it gained close to $13 \%$ of the vote. Her letter epitomises the concerns with political representation and statehood that, I suggest, are crucial in attempts to understand the consequences of the so-called refugee crisis. The term is misleading: it positions ethnic and cultural questions, and asylum seekers, as agents of chaos and emergency, and thereby downplays institutional shortcomings in a foreseeable humanitarian emergency. The crisis of public administration opened up spaces for civil society engagement that challenged political centrism and allowed minorities to renew their civic identity as responsible and reliable citizens-including those who lacked access to formal citizenship through passports. Civic engagement illustrated expectations regarding state responsibility and the capacity of public institutions: after years of budget cuts, fractures across society revealed the divisive impact of austerity in a state that struggled with challenges. Concerns over social infrastructure, on the one hand, and worries about national security and public safety, on the other, produced critical voices from initiatives such as Moabit Hilft!, and also gave support to new authoritarian nationalism.

Frustration with progressive conservatism could no longer be contained within the CDU. Alongside emboldened minority groups and pro-diversity civil society activists, the AfD emerged to claim better political representation for their particular visions: traditional values, a strong state, and powerful national identity. Only when the numbers of asylum seekers dropped significantly, and politicians committed to strengthening the state as a mediator of public life, support for the AfD dwindled slightly. The 'refugee crisis' and its impact on public administration were a catalyst that accelerated pre-existent discontent with austerity and multicultural liberalism. At a time characterised as a national crisis, the polarisation between Willkommenskultur and AfD support revealed the divisive consequences of cuts and austerity measures. It remains to be seen whether emergent civil society engagement will translate into durable political identities and change the role of minority groups permanently, or whether their crisis-induced visibility will be reduced again. At any rate, austerity-induced gaps in public institutions resulted in new types of political behaviour and civic identity. In addition to concrete help, refugee support groups vocally demanded state engagement and official responsibility for the management of challenging circumstances. Minority-led initiatives could showcase their work and demand collaboration with official bodies, funding for social projects, and recognition for their claims to belonging. 
Open Access This article is distributed under the terms of the Creative Commons Attribution 4.0 International License (http://creativecommons.org/licenses/by/4.0/), which permits unrestricted use, distribution, and reproduction in any medium, provided you give appropriate credit to the original author(s) and the source, provide a link to the Creative Commons license, and indicate if changes were made.

\section{References}

Ahonen, P. (2003). After the expulsion. In West Germany and Eastern Europe 1945-1990. Oxford: Oxford University Press.

Bade, K. J. (2007). Versäumte Integrationschancen und nachholende Integrationspolitik. In H.-G. Hiesserich (Ed.), Nachholende Integrationspolitik und Gestaltungsperspektiven der Integrationspraxis (pp. 21-95). Göttingen: V\&R Unipress.

Bade, Klaus J 2013a. Als Deutschland zum Einwanderungsland wurde. <http://www.zeit. de/gesellschaft/zeitgeschehen/2013-11/einwanderung-anwerbestopp/komplettansicht>. Accessed 8 Jun 2017.

Bade, K. J. (2013b). Kritik und Gewalt. In Sarrazin-Debatte, "Islamkritik" und Terror in der Einwanderungsgesellschaft. Schwalbach/Taunus: Wochenschau-Verlag.

Bebnowski, D. (2015). Die Alternative für Deutschland-Aufstieg und gesellschaftliche Relevanz einer populistischen Partei. Wiesbaden: Springer.

Beck, U. (1992). Risk society: towards a new modernity. Translated by Mark Ritter. London: Sage Publications.

Beck, U. (2012). Das deutsche Europa-Neue Machtlandschaften im Zeichen der Krise. Berlin: Suhrkamp.

Beck, U. (2013). German Europe. Translated by Rodney Livingstone. Cambridge \& Malden (MA): Polity Press.

Blyth, M. (2013). Austerity - the history of a dangerous idea. Oxford: Oxford University Press.

Braunthal, G. (2003). The SPD, the welfare state, and agenda 2010. German Politics and Society, 21(4), 1-29.

Buschkowsky, H. (2012). Neukölln ist überall. Berlin: Ullstein Verlag.

Çakir, N. (2014). Islamfeindlichkeit. Anatomie eines Feindbildes in Deutschland. Bielefeld: transcript.

Camerra-Rowe, P. (2004). Agenda 2010: redefining German social democracy. German Politics and Society, 22(1), 1-30.

Caspari, L. (2012). 'Sozialdemokraten sorgen sich um Wähler.' Zeit Online. http://www.zeit. de/politik/deutschland/2012-05/spd-schleswig-holstein/komplettansicht. Aaccessed 16 Jan 2017.

Clark, T., \& Heath, A. (2014). Hard times: the divisive toll of the economic slump. London: Yale University Press.

Cohen, S., Fuhr, C., \& Bock, J.-J. (Eds.). (2017). Austerity, community action, and the future of citizenship in Europe. Bristol: Policy Press.

della Porta, D. (2015). Social movements in times of austerity: bringing capitalism back into protest analysis. Malden: Polity Press.

Eddy, M., \& Johannsen, K.. (2015). 'Migrants arriving in Germany face a chaotic reception.' The New York Times, 27 November, A10.

Elgenius, G. (2017). Social division and resentment in the aftermath of the economic slump. In S. Cohen, C. Fuhr, \& J.-J. Bock (Eds.), Austerity, community action, and the future of citizenship in Europe. Bristol: Policy Press.

Foroutan, N. (2015). Wir brauchen ein neues Leitbild. DER SPIEGEL, 42, 32-34.

Funke, H. (1993). Brandstifter: Deutschland zwischen Demokratie und völkischem Nationalismus. Göttingen: Lamuv.

Graeber, D. (2008). Direct action: An ethnography. Oakland: AK Press.

Graeber, D. (2012). The democracy project: a history, a crisis, a movement. New York: Spiegel \& Grau.

Haiven, M., \& Khasnabish, A. (2014). The radical imagination: social movement research in the age of austerity. London: Zed Books.

Hassel, A., \& Schiller, C. (2010). Der Fall Hartz IV. In Wie es zur Agenda 2010 kam und wie es weitergeht. New York: Campus.

Häusler, A. (Ed.). (2016). Die Alternative für Deutschland: Programmatik, Entwicklung und Politische Verortung. Wiesbaden: Springer Fachmedien.

Hegelich, S., Knollmann, D., \& Kuhlmann, J. (2011). Agenda 2010. In Strategien-EntscheidungenKonsequenzen. Wiesbaden: VS Verlag für Sozialwissenschaften.

Heinemann, K.-H., \& Schubarth, W. (Eds.). (1992). Der antifaschistische Staat entlässt seine Kinder: Jugend und Rechtsextremismus in Ostdeutschland. Cologne: PapyRossa.

Herbert, U. (2001). Geschichte der Ausländerpolitik in Deutschland: Saisonarbeiter, Zwangsarbeiter, Gastarbeiter, Flüchtlinge. München: C. H. Beck. 
Jakubowska, A. (2012). Der Bund der Vertriebenen in der Bundesrepublik Deutschland und Polen. In Selbst-und Fremddarstellung eines Vertriebenenverbandes (pp. 1957-2004). Marburg: Herder-Institut Verlag.

Jung, M. (2016). Merkels Formel der Macht - Zwischen Mitte und Modernisierung. Forschungsjournal Soziale Bewegungen, 29(3), 230-234.

Jung, M., Schroth, Y., \& Wolf, A. (2014). Wählerverhalten und Wahlergebnis: Angela Merkels Sieg in der Mitte. In K.-R. Korte (Ed.), Die Bundestagswahl 2013-Analysen der Wahl-, Parteien-, Kommunikations- und Regierungsforschung (pp. 35-53). Wiesbaden: Springer Fachmedien.

Karakayali, S., \& Kleist, O. J. (2015). In Berliner Institut für empirische integrations- und Migrationsforschung (Ed.), Strukturen und Motive der ehrenamtlichen Flüchtlingsarbeit (EFA) in Deutschland. Berlin: HumboldtUniversität zu Berlin.

Karakayali, S., \& Kleist, O. J. (2016). Strukturen und Motive der ehrenamtlichen Flüchtlingsarbeit (EFA) in Deutschland 2. Forschungsbericht. Edited by Berliner Institut für empirische Integrations- und Migrationsforschung. Berlin: Humboldt-Universität zu Berlin.

Klärner, A. (2001). Aufstand der Ressentiments. Einwanderungsdiskurs, Völkischer Nationalismus und die Kampagne der CDU/CSU gegen die doppelte Staatsbürgerschaft. Cologne: PapyRossa.

Kosnick, K. (2019). New Year's eve, sexual violence and moral panics: Ruptures and continuities in Germany's integration regime. In J.-J. Bock \& S. Macdonald (Eds.), Refugees Welcome? Difference and Diversity in a Changing Germany. Oxford: Berghahn Books.

Kossert, A. (2008). Kalte Heimat - Die Geschichte der Deutschen Vertriebenen nach 1945. München: Siedler Verlag.

Laurence, J., \& Lim, C. (2015). Doing good when times are bad: volunteering behaviour in economic hard times. Br J Sociol, 66(2), 319-344.

Locke, S.. (2014). Die neue Wut aus dem Osten. http://www.faz.net/aktuell/politik/inland/pegida-bewegunggegen-islamisierung-des-abendlandes-13306852.html. Accessed 28 March 2017.

Loginov, M. (2017). Muslim- Und Islamfeindlichkeit in Deutschland. In Begriffe Und Befunde Im Europäischen Vergleich. Wiesbaden: Springer Fachmedien.

Losse, B.. (2015). 'Die Deutschen sorgen sich um ihre Sicherheit.' Wirtschaftswoche. http://www.wiwo. de/politik/deutschland/allensbach-umfrage-die-deutschen-sorgen-sich-um-ihre-sicherheit/12737298.html. Accessed 17 Jan 2017.

Mandel, R. (2008). Cosmopolitan Anxieties: Turkish challenges to citizenship and belonging in Germany. Durham: Duke University Press.

Meng, M. (2015). Silences about Sarrazin's racism in contemporary Germany. J Mod Hist, 87(1), 102-135.

Muehlebach, A. (2016). Camp in the city. https://culanth.org/fieldsights/907-camp-in-the-city. Accessed 28 May 2017.

Nökel, S.. (2002). Die Töchter der Gastarbeiter und der Islam: Zur Soziologie alltagsweltlicher Anerkennungspolitiken. Eine Fallstudie Bielefeld: transcript.

Pagenstecher, C. (2008). 'Das Boot Ist Voll'. Schreckensvision Des Vereinten Deutschland. In Das Jahrhundert Der Bilder. Band Ii: 1949 Bis Heute, edited by Gerhard Paul, 606-613. Göttingen: Schriftenreihe der Bundeszentrale für politische Bildung, Band 734.

Panayi, P. (1994). Racial violence in the New Germany. Contemp Eur Hist, 3(3), 265-287.

Petersen, T. (2015). 'Ein Volk kommt zur Ruhe.' Frankfurter Allgemeine Zeitung, 28 January, 8.

Quent, M. (2015). “'Rechtsextremismus als Ost-Problem darzustellen, ist gefährlich”.' Zeit Online. http://www. zeit.de/gesellschaft/zeitgeschehen/2015-08/rechtsextremismus-soziologie-neonazis-heidenau. Accessed 17 Jan 2017.

Resing, V. (2013). Die Kanzlermaschine-Wie die CDU funktioniert. Freiburg im Breisgau: Herder Verlag.

Sarrazin, T. (2010). Deutschland schafft sich ab. Wie wir unser Land aufs Spiel setzen. Munich: Random House.

Schiffauer, W. (2019). Refugees Welcome? Difference and Diversity in a Changing Germany. In J.-J. Bock \& S. Macdonald (Eds.), Oxford: Berghahn Books.

Schmid, T. (2015). Doch, der Fremdenhass ist ein Ost-Problem. https://www.welt. de/debatte/kommentare/article145880767/Doch-der-Fremdenhass-ist-ein-Ost-Problem.html. Accessed 17 Jan 2017.

Schmidt, M. G. (2015). Die Sozialpolitik der CDU/CSU-FDP-Koalition von 2009 bis 2013. In R. Zolnhöfer \& T. Saalfeld (Eds.), Politik im Schatten der Krise - Eine Bilanz der Regierung Merkel 2009-2013 (pp. 397426). Wiesbaden: Springer Fachmedien.

Schui, F. (2014). Austerität. Politik der Sparsamkeit. Die kurze Geschichte eines großen Fehlers. Munich: Karl Blessing.

Schwarzer, A. (Ed.). (2016). Der Schock - Die Silvesternacht von Köln. Köln: Kiepenheuer \& Witsch.

Seils, C. (2013). 'Warum die CDU der SPD die Themen klaut.' Cicero. http://cicero.de/berlinerrepublik/wahlkampf-2013-warum-die-cdu-der-spd-die-themen-klaut/54608. Accessed 16 Jan 2017. 
Stewart, C., \& Knight, D. M. (2016). Ethnographies of austerity: temporality, crisis and affect in southern Europe. Hist Anthropol, 27(1), 1-18.

Strauß, S. (2008). Volunteering and social inclusion: interrelations between unemployment and civic engagement in Germany and Great Britain. Wiesbaden: VS Verlag für Sozialwissenschaften.

The Economist. (2015). Austere? Your word, not ours. http://www.economist.com/news/europe/21657839-ifanything-germans-are-more-hawkish-greece-their-leaders-austere-your-word-not-ours. Accessed 19 June.

Wowtscherk, C. (2014). Was wird, wenn die Zeitbombe hochgeht? Eine sozialgeschichtliche Analyse der fremdenfeindlichen Ausschreitungen in Hoyerswerda im September 1991. Göttingen: V\&R Unipress.

Zolleis, U., \& Schmid, J. (2014). Die CDU unter Angela Merkel - Der neue Kanzlerwahlverein? In O. Niedermayer (Ed.), Die Parteien nach der Bundestagswahl 2013 (pp. 25-48). Wiesbaden: Springer Fachmedien. 